\title{
IMPACTS ON THE CONSUMPTION OF ELECTRIC POWER BY THE USE OF EFFICIENT REFRIGERATORS - ECUADOR CASE
}

\author{
IMPACTOS EN EL CONSUMO DE ENERGÍA \\ ELÉCTRICA POR EL USO DE REFRIGERADORES \\ EFICIENTES - CASO ECUADOR
}

\author{
Nelson G. Jara ${ }^{1, *}$, Fran Z. Reinoso ${ }^{1}$, Cesar Isaza-Roldán ${ }^{2}$, Juan Leonardo Espinoza ${ }^{3}$
}

\begin{abstract}
This article presents an analysis of the impacts that the Renova Refrigerator program will have, on electricity consumption in Ecuador; the main objective of this program is to replace refrigerators that are more than 10 years old with efficient class "A" domestic refrigerators. The development and implementation of the program reduces energy consumption by $8 \%$, motivates people to use electric energy efficiently and encourages the national industry to use new technologies, which increases productivity and domestic product consumption. Additionally, in compliance with the current Ecuadorian and international regulations, the variation in electricity consumption of a domestic refrigerator is evaluated when it runs at the different temperatures determined by the thermal floors, which are very distinct in the Coast, Sierra and eastern regions of Ecuador.
\end{abstract}

Keywords: domestic refrigerator, energy saving, energy consumption, Renova Refrigerator program, energy efficiency.

\section{Resumen}

En este artículo se presenta un análisis de los impactos que tendrá el programa «Renova Refrigerador», en el consumo de energía eléctrica en el Ecuador; programa que tiene como principal objetivo la renovación de refrigeradores domésticos eficientes etiquetados con A, por refrigeradores ineficientes y con una vida útil que ha sobrepasado los diez años. Su desarrollo e implementación contribuye a la reducción de consumo energético en un $8 \%$, motiva a la población a utilizar la energía eléctrica de manera eficiente e impulsa a la industria nacional en el uso de nuevas tecnologías incrementando así la productividad y el consumo de productos nacionales. Bajo el cumplimiento de la normativa vigente ecuatoriana y sus similares internacionales; se considera, además, la variación en el consumo eléctrico que presenta un refrigerador doméstico cuando trabaja a distintas temperaturas, determinadas por los pisos térmicos, marcados plenamente en el Ecuador por las regiones Costa, Sierra y Oriente.

Palabras clave: refrigerador doméstico, ahorro de energía, programa Renova Refrigerador, eficiencia energética.

\footnotetext{
${ }^{1, *}$ Grupo de Investigación y Desarrollo en Simulación Optimización y Toma de Decisiones, Universidad Politécnica Salesiana, Ecuador Autor para correspondencia: njara@ups.edu.ec. (D) http://orcid.org/0000-0003-0299-7089, (D) http://orcid.org/0000-0001-8228-2336

${ }^{2}$ Centro de Investigación en Refrigeración y Aire Acondicionado, Universidad Pontificia Bolivariana de Medellín, Colombia. (D) http://orcid.org/0000-0002-5902-6411

${ }^{3}$ Grupo de Investigación en Energía y Sistemas Eléctricos, Universidad de Cuenca, Ecuador.

(D) http://orcid.org/0000-0002-7450-2084
}

Recibido: 24-04-2017, aprobado tras revisión: 25-05-2017

Forma sugerida de citación: Jara, N.; Reinoso, F.; Isaza-Roldán, C.; Espinoza, J. (2017). «Impacts on the consumption of electric power by the use of efficient refrigerators - Ecuador case». INGENIUs. N. ${ }^{\circ} 18$, (julio-diciembre). pp. 53-63. ISSN: $1390-650 \mathrm{X}$ 


\section{Introduction}

The increased global energy demand due to human development encourages governments to establish policies to maintain control of energy expenditure and to prioritize environmental protection, thus minimizing the emission of greenhouse gases, particularly $\mathrm{CO}_{2}$. The mechanisms to achieve these purposes are the following: rationing resources and promoting the use of new technologies with higher efficiency.

In accordance with this global trend, plans and programs are being implemented in Ecuador to decrease energy consumption, especially electrical energy due to its ease of control and implementation. Among the implemented programs we can mention the following: a light bulb substitution program to replace incandescent lamps with compact fluorescent lamps, energy efficiency for induction cooking, efficient public lighting, industrial energy efficiency, and a program for the replacement of domestic refrigerators $[1,2]$.

The energy efficiency program for the replacement of domestic refrigerators called the Renova Refrigerator seeks to replace 330,000 refrigerators more than 10 years old in Ecuadorian households. This program has been in effect since the middle of 2011, and its main goal is to save 215.780 MWh of electric energy per year, which represents approximately 27 million dollars, assuming an energy cost of $12.5 \mathrm{cUSD} / \mathrm{kWh}[3,4]$.

The household appliance industry is generally structured into two groups. The first group is for major appliances, which are stationary units due to their large size. This group includes stoves, ovens, fans, exhaust hoods, air conditioners, water heaters, dishwashers, clothes washers and dryers, refrigerators, and freezers. The second group is for small appliances and includes vacuum cleaners, blenders, food grinders or processors, fruit juicers, blenders, toasters, microwave ovens, razors and hair clippers and hairdryers [5].

In Ecuador, the largest production of white goods comprises the manufacture and assembly of refrigerators, freezers, stoves, washing machines and microwave ovens. The national production of parts and components supplies $50 \%$ of the manufacturer requirements of home appliances, which could increase by $30 \%$ based on the installed capacity.

In the market, there are four major companies dedicated to the production of stoves and refrigerators that supply the national demand and are also able to export their products: Mabe, Induglob/Indurama, Durex and Ecogar. In Ecuador, stoves and refrigerators are marketed by companies such as Comandato, Orve Hogar, Almacenes Japón, and Créditos Económicos [6]. As discussed later, the use of refrigerators is widespread in Ecuador and represents between $40 \%$ and $60 \%$ of the electricity demand of the residential sector [2].

In addition, by analyzing the contemporary history of the energy supply of Ecuador, it has been possible to identify a series of events that destabilized the country's economy and also affected its energy sector. In addition, some government policies did not have a major impact on the development of the sector, paralyzed projects that had studies underway and led to a lack of institutionalization of public energy companies.

Ecuador was affected by natural disasters including the following: the El Niño phenomenon in 1982-83 and in 1997-98 that caused serious problems for the population, an earthquake in 1987 that interrupted the production and export of oil for several months; the Josefina disaster in the south of the country in 1993 that seriously affected the Paute hydroelectric complex, and severe low river water levels that contributed to a prolonged energy crisis which included electric power rationing. In addition, the permanent diplomatic and military tension with Peru resulted in open armed conflicts on two occasions between 1981 and 1995 [7]. Furthermore, the Ecuadorian Institute of Electrification (Instituto Ecuatoriano de Electrificación - INECEL) developed a systematic work on urban and rural electrification starting in 1976 [8], forcing the government to take strong economic measures that also affected the energy sector.

In July of 2007, by Executive Decree No. 475, the Ministry of Electricity and Renewable Energy (Ministerio de Electricidad y Energía Renovable - MEER) was created. From its various agencies, MEER manages various plans, programs and projects related to energy efficiency and their impacts on energy consumption [2]. The specific case cited in this paper is the Renova Refrigerator program related to the use of efficient refrigerators in Ecuador.

\section{Status of the electricity sector and household refrigeration appliances in Ecuador.}

Nowadays, Ecuador produces renewable energy from hydraulic, solar, wind and cogeneration thermal sources and non-renewable energy from sources such as thermal turbo-gas, thermal turbo-steam and internal combustion engines $[9,10]$.

The Coordinating Ministry of Strategic Sectors (Ministerio Coordinador de Sectores Estratégicos MICSE) has prepared energy assessments for Ecuador where the energy flows are accounted for in each stage of the energy chain, from the time of production or extraction of the primary sources to the acquisition of secondary sources, including an intermediate process of transformation [11].

Tables 1, 2 and 3 show the statistical information of the effective electricity generation capacity (MW), energy delivered for public service (GWh) and energy consumption for public service (GWh) as of May 2015, respectively [12]. 
Table 1. Effective electricity generation capacity in Ecuador [12]

\begin{tabular}{ccr}
\hline \multicolumn{2}{c}{ Effective generation capacity } & \multicolumn{1}{c}{ MW } \\
\hline & Hydraulic & $2,354.20$ \\
Renewable & Solar & 26.37 \\
Energy & Wind & 21.15 \\
& Turbo-steam & 136.4 \\
Total Renewable Energy & $2,538.12$ \\
\hline \multirow{3}{*}{ Non-Renewable } & Internal combustion & $1,482.12$ \\
Energy & engines & 977.3 \\
\multicolumn{3}{c}{ Total Non-Renewable Energy } \\
Total Effective Capacity & $2,907.66$ \\
& Turbo-gas & $5,445.77$ \\
\hline
\end{tabular}

Table 2. Energy delivered for public service [12]

\begin{tabular}{ccr}
\hline \multicolumn{2}{c}{$\begin{array}{c}\text { Energy delivered for public } \\
\text { service }\end{array}$} & \multicolumn{1}{c}{ GWh } \\
\hline & Hydraulic & $124,362.53$ \\
Renewable & Solar & 27.98 \\
Energy & Wind & 85.78 \\
& Turbo-steam & 273.23 \\
Total Renewable Energy & $12,849.52$ \\
\hline & Internal combustion \\
Non-Renewable & engines \\
Energy & Turbo-gas & $3,594.60$ \\
\multicolumn{3}{c}{ Turbo-steam } \\
Total Non-Renewable Energy & $2,336.52$ \\
Total National Production & $8,263.61$ \\
Interconnection Imports & $21,144.26$ \\
Total Energy Delivered for & 840.43 \\
Public Service & $21,974.69$ \\
\hline
\end{tabular}

Table 3. Energy consumption for public service and collections in millions of dollars [12]

\begin{tabular}{ccc}
\hline $\begin{array}{c}\text { Energy consumption for public } \\
\text { service }\end{array}$ & MW \\
\hline & Residential & $6,537.42$ \\
National energy & Commercial & $3,873.93$ \\
consumption & Industrial & $5,384.17$ \\
& Street lighting & $1,046.39$ \\
& Other & $1,882.00$ \\
Total & $2,538.12$ \\
\hline \multicolumn{3}{c}{ Technical } \\
Distribution losses & Non-technical \\
Total energy distribution losses & $2,636.08$ \\
Collections Billed in USD (millions) & $1,744.50$ \\
USD Collected (millions 98.67\%) & $1,726.25$ \\
\hline
\end{tabular}

Table 4 shows the concession areas of the power distribution companies in Ecuador and their business unit abbreviations.

Table 4. Concession areas of power distribution companies in Ecuador [13]

\begin{tabular}{ccc}
\hline Company & $\begin{array}{c}\text { Concession area } \\
\left(\mathbf{k m}^{2}\right)\end{array}$ & $\begin{array}{c}\text { Contribution } \\
\mathbf{( \% )}\end{array}$ \\
\hline CNEL-Bolívar (BOL) & $4,071.20$ & 1.59 \\
CNEL-El Oro (EOR) & $6,672.00$ & 2.60 \\
CNEL-Esmeraldas (ESM) & $15,027.63$ & 5.86 \\
CNEL-Guayas Los Ríos (GLR) & $10,515.54$ & 4.10 \\
CNEL.- Los Ríos (LRS) & $4,021.80$ & 1.57 \\
CNEL - Manabí (MAN) & $16,678.53$ & 6.50 \\
CNEL.- Milagro (MLG) & $4,994.54$ & 1.95 \\
CNEL - Sta. Elena (STE) & $6,587.01$ & 2.57 \\
CNEL - Santo Domingo (STD) & $6,658.47$ & 2.60 \\
CNEL - Sucumbíos (SUC) & $37,990.46$ & 14.81 \\
EE. Ambato (E. Centro Norte) & $41,116.71$ & 16.03 \\
EE. Azogues & $1,150.40$ & 0.45 \\
EE. Centro Sur (EERCS) & $30,243.22$ & 11.79 \\
EE. Cotopaxi & $5,645.37$ & 2.20 \\
EE. Galápagos & $8,224.39$ & 3.21 \\
EE. Norte (E. Regional Norte) & $12,420.59$ & 4.84 \\
EE. Quito (EEQ) & $14,725.00$ & 5.74 \\
EE. Riobamba & $5,934.10$ & 2.31 \\
EE. Sur (EERSSA) & $22,716.12$ & 8.86 \\
EE. Guayaquil (GUA) & $1,054.96$ & 0.41 \\
\hline
\end{tabular}

Figure 1 shows the power distribution companies of Ecuador and their geographical locations.

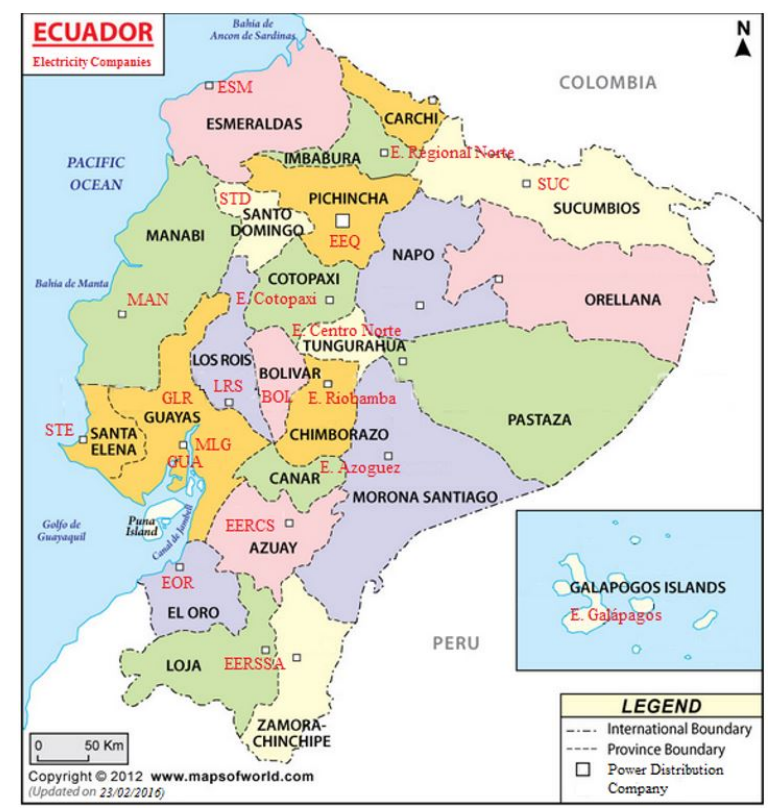

Figure 1. Identification of energy distribution companies in Ecuador.

\subsection{Electricity supply growth in Ecuador.}

In Ecuador, the National Development Plan (PND) is the instrument governing public policies, programs and projects, as well as investments and allocation of resources. In 2008 in Montecristi the new constitution of the Republic of Ecuador was established, mainly based on positions to be taken to promote social, economic 
and territorial equity. As well as principles which set as a priority the eradication of poverty ware raised, promoting sustainable and equitable distribution of wealth and development, in this sense the national development plan became the National Plan for Good Life (Plan Nacional para el Buen Vivir - PNBV). As part of the proposed strategies for achieving the PNBV objectives, changing the energy matrix is essential, and encompasses the following components:

- To increase the share of renewable energies in the generation matrix, mainly through hydroelectric projects.

- To reduce petroleum derivatives imports through construction of the Pacific Refinery.

- To encourage efficient energy use by reducing the consumption of petroleum derivatives by residential customers.

In order to execute these components, the new Master Plan for Electrification of Ecuador 2013-2022 (Plan Maestro de Electrificación - PME) was formulated, it seeks to modernize and expand the electricity system, given the availability of sufficient energy reserves to ensure the natural growth of domestic demand, the addition of new loads entailed in changing the country's energy matrix, the opportunity to optimize operating costs offered by the current international connections, and the opportunity to increase the transfer volumes enabling the country to participate proactively in the regional electricity market.

In 2013, Ecuador's electricity network had installed a power generation capacity of 5,100 MW, of this the $46 \%$ corresponded to renewable energies and the $54 \%$ to thermal energies. In order to meet much of the projected demand, new hydroelectric projects are under construction for an additional capacity of 4,165 MW; of these, eight are considered flagship projects, equivalent to 2,362 MW. These projects, located on the Amazon and Pacific sides of the divide, are currently operating, adding more capacity in 2016 and 2017.

The actions above had their reason for being primarily implemented by the different energy efficiency policies in the country during the last 5 years. As a special case and intended to eliminate the petroleum liquid gas subsidy, the energy efficiency program for induction cooking is being implemented, it will have a direct impact on demand in the residential sector. This will require an average annual power of 5,457 GWh by late 2022 .

Furthermore, in the period between 1999 and 2005, the growth of the effective capacity from renewable sources was almost zero, while in the period from 2006 to 2011 , it was $4.6 \%$. In addition, the effective capacity from non-renewable internal combustion systems grew $16.4 \%$ in the period of 2005-2011; in turbo-gas systems, it grew $16 \%$ [14]. It is important to mention that since 2013, projects with renewable energy sources connected to the National System have been incorporated, such as the Villonaco wind project and several photovoltaic parks.

\subsection{Electricity demand in Ecuador.}

The electricity demand in the period of 1999-2011 had a growth rate of $5.8 \%$. By February 2015, the total consumption, including technical and non-technical distribution losses, was $21,352.70 \mathrm{GWh}$, of which $6,537.42$ GWh were from residential consumption, 3,873.93 GWh were from commercial consumption, 5,834.17 GWh were from industrial consumption, 1,046.39 GWh were from street lighting consumption, and 1,882 GWh were from other consumption sources [12].

The technical and non-technical distribution losses in the electrical consumption were $1,736.08 \mathrm{GWh}$ $(8.13 \%)$ and $892.70 \mathrm{GWh}(4.18 \%)$, respectively (see Table 3).

According to the 2010 Population and Housing Census by the National Institute of Statistics and Censuses (Instituto Nacional de Estadísticas y Censos INEC), the total percentage of dwellings with electric power reached $94.77 \%$, in the urban area, while it was $89.03 \%$ in rural areas [15].

The Guayas province has the highest number of subscribers, the same as in the year 2010, when 43,548 households without access to electricity it ware recorded, which corresponds to approximately $5 \%$ of the provincial total. These problems are also evident in other provinces, especially those that are located in the eastern part of the country. In this regard the Ministry of Electricity and Renewable Energy - MEER According to the institutional strategic plan 2014-2017, aims to cover $96,88 \%$ of the national electricity service of the public distribution.

Until 2010, the characterization of the consumption of end uses of electricity for residential customers of Ecuador had not been updated, therefore it had only the study conducted in 1991 and data was insufficient to be used as a basis for the development of the domestic refrigerators renewal plan.

For this reason in 2010 MEER, through consultancy, conducted a new analysis of some cities' energy consumption in lighting, cooling, water heating and other (in this category is cooking with electricity) and determined that residential consumption in Ecuador for the 2010 represented $35 \%$ of the national electrical consumption [16]. The development of the study of end uses of energy was based on the measurement and construction of load curves and use perception surveys. The results showed that increased consumption was generated by the use of domestic refrigeration equipment, with an average of $43.2 \%$ in relation to the residential consumption. 
According to data from INEC, based on the 20112012 National Survey of Income and Expenditure of Urban and Rural Households (Encuesta Nacional de Ingresos y Gastos de Hogares Urbanos y Rurales ENIGHUR) [17], there are 2,964,158 refrigerators in Ecuador, which represents a penetration rate of $75.96 \%$. Segmenting it by regions shows that in the Coast, there are $1,620,605$ units with a penetration rate of $80.1 \%$, the Sierra has 1,219,039 units with a penetration rate of $71.2 \%$, the Amazon has 116,968 units with a penetration rate of $65.2 \%$ and the Galapagos has 7,518 units with a penetration rate of $86.6 \%$ [17].

The projection of domestic refrigerator acquisitions for the residential sector in Ecuador, submitted by the electricity companies for 2009 and prepared by MEER, establishes that there are 1,379,904 units in households with a power consumption rate of up to $200 \mathrm{kWh} /$ month, of which 1 of every 4 units can be assumed to be more than 10 years old. These are the candidates for replacement according to the Renova plan. Based on this estimate, there are 330,000 units that can be updated [18].

In 2009, the Ecuadorian Technical Regulation RTE INEN 035:2009 "Energy efficiency in household refrigerating appliances. Report on energy consumption, testing methods and labelling" went into effect for units that are nationally manufactured or those that are imported and are marketed in the Republic of Ecuador. This technical regulation establishes the requirement that household refrigeration equipment of up to 850 liters (approx. $30 \mathrm{ft}^{3}$ ), must categorize their energy consumption and efficiency rate with letters from A to $\mathrm{G}$, where $\mathrm{A}$ is the most efficient equipment and $\mathrm{G}$ is the least efficient.

A second amendment made to the Regulation mentioned above allows marketing only class $\mathrm{A}$ and $\mathrm{B}$ domestic refrigerators of up to 850 liters equipped with hermetic compressors from December 01, 2010 until March 01, 2011. As of March 02, 2011, only class A can be marketed. For the first time, the use of minimum energy performance standards (MEPS) as a control has also been incorporated.

According to the Renova Technical Annex by MEER, refrigerators with energy efficiency classes of $\mathrm{E}$ through G were marketed until 2007, and the average consumption was $735 \mathrm{kWh} /$ year. After implementing Regulation RTE INEN 035:2009, the consumption of the appliances ranged from 250 to $450 \mathrm{kWh} /$ year depending on the size and efficiency class, which could be A, B or C. Currently, with the obligation to market only class A, average savings of $350 \mathrm{kWh} /$ year are achieved for the vast majority of the appliances [3].

Service life is another variable that has a negative impact on the energy efficiency of domestic refrigerators. According to the national seminar on the electricity sector carried out in May 2010 in the city of Azogues, $48.2 \%$ of the population owns refrigerators more than 10 years old, and $25.9 \%$ owns refrigerators more than 15 years old. These units consume more than $1000 \mathrm{kWh} /$ year [19].

The useful life period of a domestic refrigerator is estimated at approximately 15 years, and according to the data presented in the previous paragraph, a lot of domestic refrigerators in the country are about to fulfill it and others have already surpassed that life period, added to this existing technological problems by incorrect maintenance, improper use and the influence of temperature, according to thermal zones, while operating the equipment, cause continuous starts of the system, dramatically elevating its energy consumption.

Refrigerators with higher percentage of sales in the country are those with two doors, with the freezer on top and with capacities between 10 and 12 cubic feet, these refrigerators presented by 1991, an average consumption of $708 \mathrm{kWh} /$ year in the sierra region and $1087 \mathrm{kWh} /$ year in the coast region, by 1999 technological improvements were incorporated by manufacturers, causing consumption to decrease to $634 \mathrm{kWh} /$ year in the sierra region and $885 \mathrm{kWh} /$ year in the coast region; by 2014, according to label, energy consumption is in the order of $398 \mathrm{kWh} /$ year, demonstrating the technological change that has directly influenced on the energy efficiency of equipment.

\section{Calculation methodology.}

The methodology used in this analysis is based on the document "Renovadora Technical Annex for the Operational and Economic-Financial Implementation of the Program for the Renewal of Equipment with Inefficient Energy Consumption", whose procedure for the calculation of savings is the following [18]:

- To obtain a "sample of acceptable beneficiaries" for each refrigerator brand

- To obtain the average consumption in the two months prior to the registered delivery of the refrigerator (month "A")

- To obtain the average consumption in the two months following the delivery of the refrigerator (month "P")

- To determine the difference between the consumption values of month $\mathrm{A}$ and month $\mathrm{P}$

- If the $\mathrm{A}-\mathrm{P}$ value is greater than zero, the subscriber is considered an acceptable user for achieving savings

To calculate the savings of the sample of acceptable beneficiaries, the following procedure is followed:

- To obtain the average consumption of the two months prior to the delivery of the refrigerator 
- To obtain the average consumption of the two months following the delivery of the refrigerator

- To obtain the positive difference between the two averages for each of the beneficiaries

- To add all of the savings from each of the beneficiaries of the sample

Taking the average of the savings obtained from the sample.

\section{Energy impact analysis.}

The application of minimum energy performance standards - MEPS in household refrigeration equipment in the Ecuador, through the implementation of Ecuadorian Technical Regulation RTE INEN 035: 2009, which requires the manufacture and marketing of devices with efficiency class "A" in the country, has been the main support for the implementation of Renova Refrigerator program since 2012.

For the determination of electricity savings and verification of compliance with the established goals and if they have been achieved during implementation of the refrigerators renewal plan, the methodology presented in the document Renewing Technical Annex No. 4 version issued in 2014 was used, specifically with regards to monitoring and evaluation presented in Section 9.8 of the mentioned document.

Since 2007, with the creation of MEER, the institutional entities that guide the changes of the energy matrix have been restructured, strengthened and created, promoting Ecuador as a model in the management and implementation of infrastructure [3].

The following objectives are established based on the data provided in the 2014-2017 MEER strategic plan:

- To increase the supply of electric power using renewable sources from $43.1 \%$ to $60 \%$

- To expand the electricity service coverage from $95.41 \%$ to $96.88 \%$

Implement plans and programs for energy efficiency that result in savings of up to $1.448 \mathrm{GWh} /$ year including technical losses [20].

\subsection{Energy savings results}

The calculation methodology described above was validated through the analysis of the secondary information provided by the Centro Sur Energy Distribution Company, which has a concession area of $30,243.22 \mathrm{~km}^{2}$, representing a participation of $11.79 \%$ of the total area, and 362,406 regulated subscribers, representing $7.72 \%$ of the national total [21].
Table 5 shows a summary of the results obtained in the period from April to September 2014, according to data provided by EERCS. These results are based on the samples of new users that are accepted per the calculation method. The period mentioned above is the one with the most available data that clearly shows that the program implementation generates savings of approximately $30 \mathrm{kWh} /$ month per subscriber or US $\$ 3$ per month.

Table 5. Savings at EERCS due to the 2014 implementation of the Renova Refrigerator program for the analyzed period. Source: Energy consumption data of subscribers participating in the Renova Refrigerator program

\begin{tabular}{cccc}
\hline $\begin{array}{c}\text { Base } \\
\text { period }\end{array}$ & No samples & $\begin{array}{c}\text { Savings } \\
(\mathbf{k W h} / \mathbf{m o n t h})\end{array}$ & $\begin{array}{c}\text { Average } \\
(\mathbf{k W h} / \mathbf{m o n t h})\end{array}$ \\
\hline April & 105 & 3043.78 & 28.99 \\
May & 20 & 618.03 & 30.9 \\
June & 36 & 997.29 & 27.7 \\
July & 80 & 2330.72 & 29.13 \\
August & 25 & 836.65 & 33.47 \\
September & 19 & 466.52 & 24.55 \\
Total & 285 & 8292.99 & 29.1 \\
\hline
\end{tabular}

Table 6 details the savings behavior by energy rate. The average savings is $12.17 \mathrm{kWh} /$ month for a subscriber of the dignity fare (subscribers who consume up to $110 \mathrm{kWh} /$ month in the Sierra and $130 \mathrm{kWh} /$ month in the Coast, for which the power distributors charge $\$ 0.04$ per $\mathrm{kWh}$ ) compared to $28 \mathrm{kWh} /$ month for a subscriber with consumption between 110 and $220 \mathrm{kWh}$ per month. This result clearly shows that the higher the consumption is, the greater the savings are.

Figure 2 shows the expected savings per base month for the Renova Refrigerator program according to the type of consumer and the region.

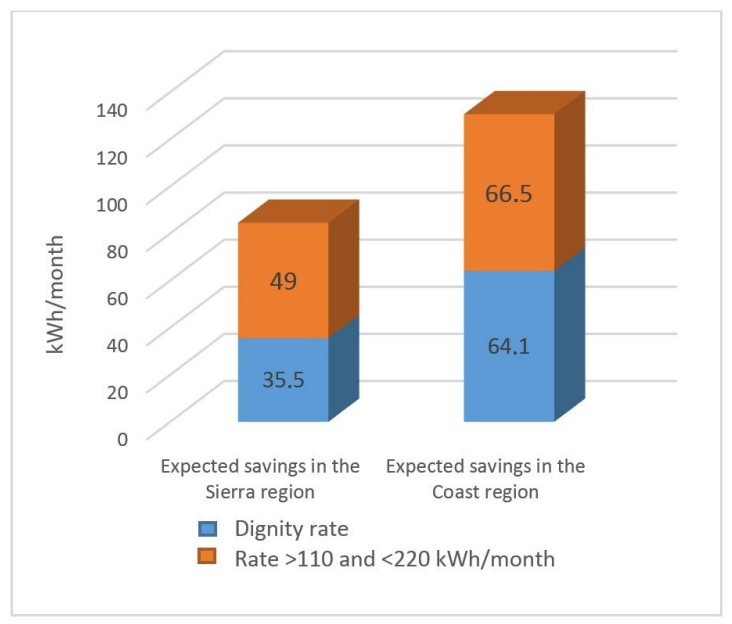

Figure 2. Expected savings per month basis for the program RENOVA Refrigerator.

Table 7 shows the calculation of lost savings, weighted using the allocation data of refrigerators for 
Table 6. Behavior of savings by energy rate

\begin{tabular}{|c|c|c|c|c|c|c|c|c|}
\hline \multirow[b]{2}{*}{ Rate type } & \multirow[b]{2}{*}{ Parameter } & \multicolumn{6}{|c|}{ Analysis period } & \multirow[b]{2}{*}{ Total } \\
\hline & & Apr-14 & may-14 & jun-14 & jul-14 & Aug-14 & sep-14 & \\
\hline \multirow{4}{*}{$\begin{array}{c}\text { Dignity rate } \\
<110 \mathrm{kWh} / \text { month }\end{array}$} & $\begin{array}{l}\text { Consumption } \\
\mathrm{kWh} / \text { month }\end{array}$ & 6826 & 1744 & 1757 & 4701 & 1759 & 1496 & 18283 \\
\hline & $\begin{array}{l}\text { New users } \\
\text { in the plan }\end{array}$ & 114 & 32 & 47 & 82 & 29 & 23 & 327 \\
\hline & $\begin{array}{c}\text { Positive difference } \\
\mathrm{kWh} / \text { month }\end{array}$ & 1490 & 331 & 405 & 1223 & 431 & 243 & 4123 \\
\hline & $\begin{array}{c}\text { Average saving } \\
\text { kWh/month }\end{array}$ & 13 & 10 & 9 & 15 & 15 & 11 & 12,17 \\
\hline \multirow{4}{*}{$\begin{array}{c}\text { Rate } \\
>110 \text { and }<220 \\
\text { kWh } / \text { month }\end{array}$} & $\begin{array}{l}\text { Consumption } \\
\mathrm{kWh} / \text { month }\end{array}$ & 7009 & 1630 & 2452 & 5517 & 2427 & 1527 & 20562 \\
\hline & $\begin{array}{l}\text { New users } \\
\text { in the plan }\end{array}$ & 48 & 11 & 17 & 39 & 16 & 10 & 141 \\
\hline & $\begin{array}{c}\text { Positive difference } \\
\mathrm{kWh} / \text { month }\end{array}$ & 1553 & 287 & 593 & 1108 & 405 & 224 & 4170 \\
\hline & $\begin{array}{l}\text { Average savings } \\
\text { kWh/month }\end{array}$ & 32 & 26 & 35 & 28 & 25 & 22 & 28 \\
\hline
\end{tabular}

EERCS, between a "real" scenario (average savings Table 6) and the expected savings in the Sierra region.

Table 7. Behavior of savings by energy rate

\begin{tabular}{ccc}
\hline Parameters & $\begin{array}{c}\text { Dignity rate } \\
\mathbf{k W h} / \mathbf{m o n t h}\end{array}$ & $\begin{array}{c}\text { Rate } \\
\mathbf{1 1 0} \text { and }<\mathbf{2 2 0} \\
\mathbf{k W h} / \mathbf{m o n t h}\end{array}$ \\
\hline $\begin{array}{c}\text { Expected savings } \\
\text { in the Sierra region } \\
\text { Real savings in } \\
\text { the Sierra region }\end{array}$ & 35.5 & 49 \\
$\begin{array}{c}\text { Allocation EERCS } \\
\text { per rate }\end{array}$ & 12.17 & 28 \\
$\begin{array}{c}\text { Expected base weighted } \\
\text { savings EERCS } \\
\text { Real base weighted } \\
\text { savings EERCS } \\
\% \text { Loss of savings }\end{array}$ & & 40.9 \\
\hline
\end{tabular}

The proposed assessment considers performing the calculation with subscribers that recently received the efficient refrigerator and have had no major changes in their energy consumption patterns. In addition, most users pay the "dignity rate" (for consumers of the lowest socio-economic stratum) and maintain an average consumption of less than $110 \mathrm{kWh}$ per month; these users behave with the greatest variance. However, the savings could be greater in the Coast region due to the weather.

Figures 3 and 4 show the allocation of domestic refrigerators by Distribution Company for the Coast and Sierra regions, respectively, in accordance with the renovation plan being studied.

Figures 5 and 6 show a projection of energy savings for the 11 distribution companies in the Coast region of Ecuador for the two proposed scenarios, optimistic or expected (Figure 5) and real or measured (Figure
$6)$, based on the data in Table 6 .

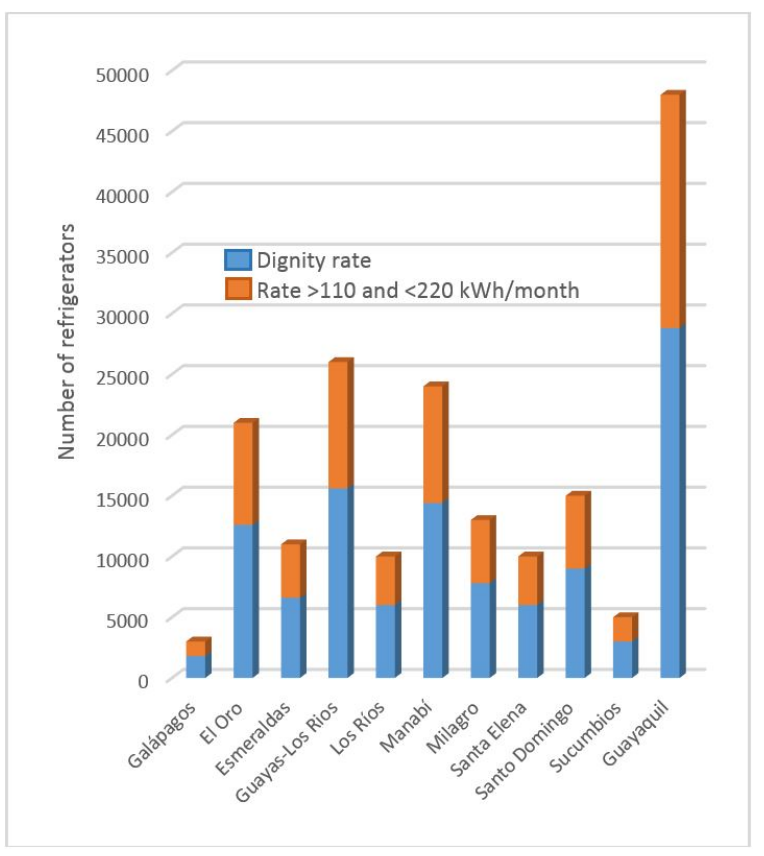

Figure 3. Allocation of domestic refrigerators, by Distribution Company - Coast region.

The total number of refrigerators for each company is taken into account; it is also assumed that the weather will adversely affect the savings. Reduced savings are therefore expected because the Coast region has a greater amount of units to install. Furthermore, a domestic refrigerator in warm weather consumes between 15 and 45 more electric power depending on its size, type and years of operation.

By comparing the average savings values in Table 6 with the expected values for the Sierra region in Figure 
2, can be observed that the estimation by MEER, in the base document of the Renova program, would not be met.

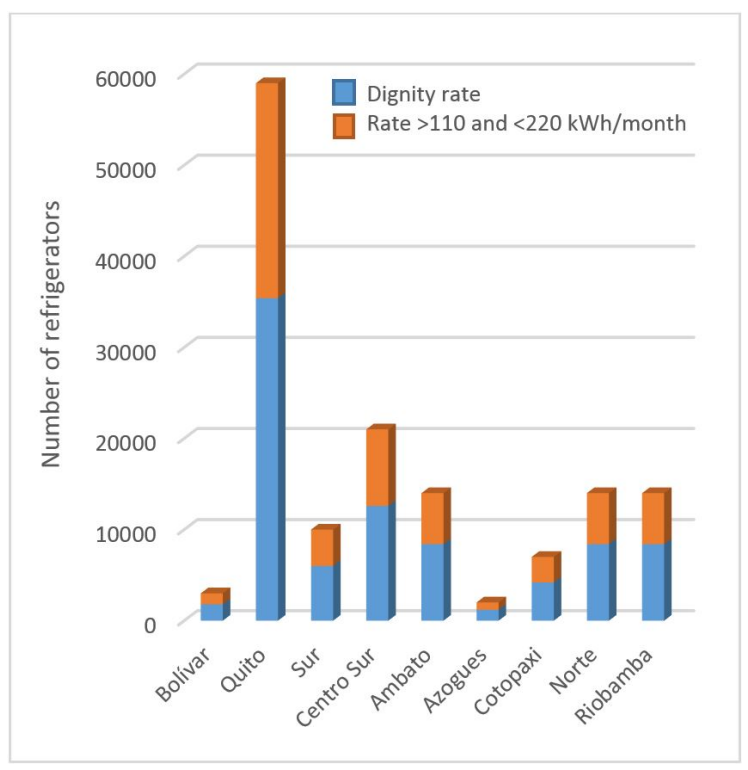

Figure 4. Allocation of domestic refrigerators, by Distribution Company - Sierra region.

Therefore, it can be said that there is a range of savings from a "real" scenario (Table 6) to an "optimistic" or expected scenario (Figure 2). With this approach, the goals of calculating the expected savings may have a significant variance, likely resulting in savings less than the $48 \%$ initially estimated (see Table 7 ).

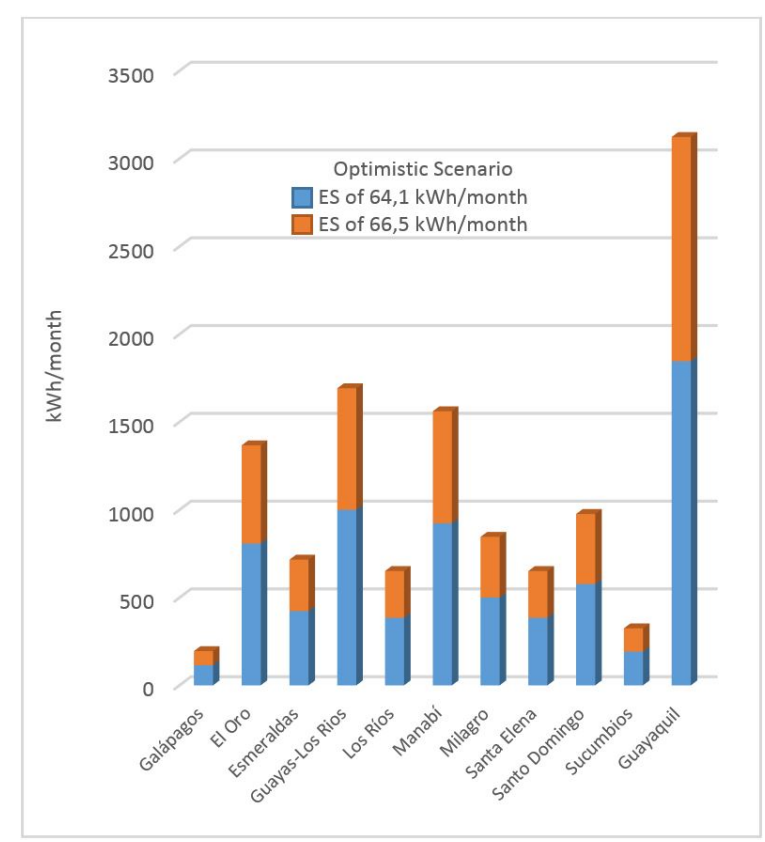

Figure 5. Electric energy savings expected. Optimistic scenario - Coast region.

Figures 7 and 8 show a projection of the energy savings for the 9 distribution companies in the Sierra region of Ecuador for the two proposed scenarios, optimistic or expected (Figure 7) and real or measured (Figure 8), based on the data of Table 6 .

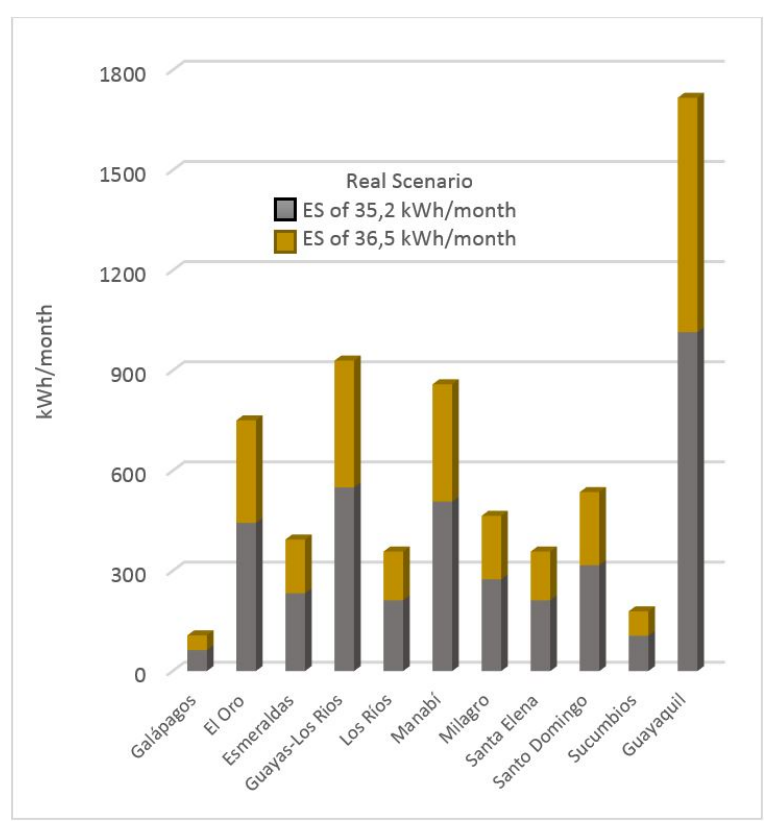

Figure 6. Electric energy savings expected. Real scenario - Coast region.

The total number of refrigerators for each company is taken into account; in addition, it is assumed that the weather will have a positive effect on the savings, which are expected to increase by $45 \%$.

Adding the savings of the Coast and Sierra regions from Figures 5 and 6 , for the real scenario, there would be a national total savings of $9.892 \mathrm{MWh} /$ month and 118.704 MWh/year.

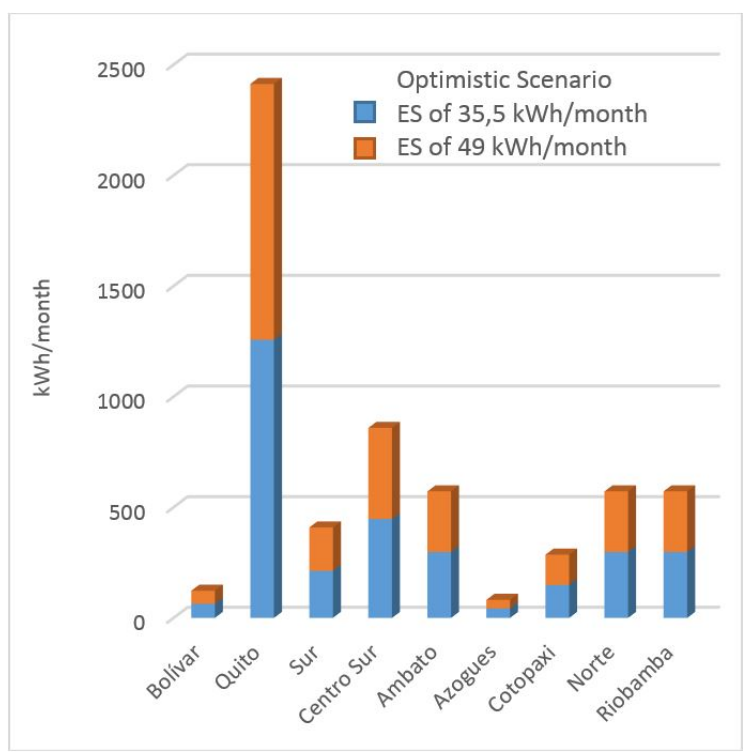

Figure 7. Electric energy savings expected. Optimistic scenario - Sierra region. 


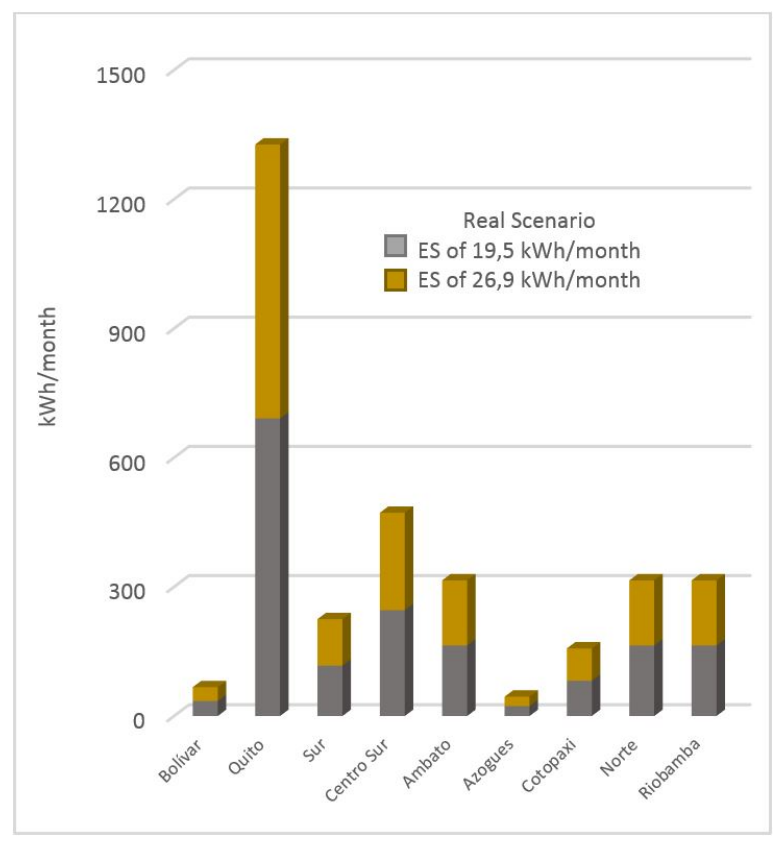

Figure 8. Electric energy savings expected. Real scenario - Sierra region.

For the optimistic scenario, there would be a national total savings of $17.991 \mathrm{MWh} /$ month and 215.892 MWh/year, which is what MEER projected as a result of implementing the Renova plan in Ecuador.

\subsection{Program implementation progress.}

The data on program implementation progress in Table 8 have a cut-off date of December 31, 2014, with the exception of 6 companies (Galápagos, Ambato, Azogues, Regional Norte and Riobamba) that have a cut-off date of April 30, 2014. Table 8 details the plan for the distribution of units by electric company and by rate level as specified in the base technical document of the program. This table includes the progress of units replaced up to the cutoff date, which represents $15 \%$ of the projected national total [18].

Considering that the program started the exchange of units in March 2012 and that the data have a cutoff date of December 2014 (approximated to 3 years), the replacement target would be 144,000 units.

However, as shown in Table 8, only 49,523 refrigeration units have been replaced. It should be emphasized that this number does not include the full 2014 data from the distributors mentioned above. Regardless, the total units replaced would show a significant delay compared to the replacement schedule because the replacement has barely met $35 \%$ of the initial goal.

The results reveal a difficulty in meeting the goal of 330,000 units replaced in 5 years, even more so considering that the fourth and fifth years constitute $56 \%$ of the implementation (186,000 units).
Table 8. Distribution and progress of the Renova Refrigerator program. [18]

\begin{tabular}{cccc}
\hline Business unit & $\begin{array}{c}\text { Renova plan } \\
\text { total } \\
\text { refrigerators }\end{array}$ & $\begin{array}{c}\text { Units replaced } \\
\text { as of Dec 2014 }\end{array}$ & $\begin{array}{c}\text { Program } \\
\text { progress } \\
\mathbf{9}\end{array}$ \\
\hline Galápagos & 3,000 & 631 & 21.03 \\
El Oro & 21,000 & 1,983 & 9.44 \\
Esmeraldas & 11,000 & 1,214 & 11.04 \\
Guayas & 26,000 & 2,97 & 11.42 \\
Los Ríos & 10,000 & 562 & 5.62 \\
Manabí & 24,000 & 6,151 & 25.63 \\
Milagro & 13,000 & 1,771 & 13.62 \\
Santa Elena & 10,000 & 946 & 9.46 \\
Santo Domingo & 15,000 & 3.236 & 21.57 \\
Sucumbíos & 5,000 & 858 & 17.16 \\
Guayaquil & 48,000 & 8,117 & 16.91 \\
Coast Total & $\mathbf{1 8 6 , 0 0 0}$ & $\mathbf{2 8 , 4 3 9}$ & $\mathbf{1 5 . 2 9}$ \\
Bolívar & 3,000 & 529 & 17.63 \\
Quito & 59,000 & 12,578 & 21.32 \\
EERSSA (Sur) & 10,000 & 1,012 & 10.12 \\
Centro Sur & 21,000 & 3,22 & 15.33 \\
Ambato & 14,000 & 1,285 & 9.18 \\
Azogues & 2,000 & 399 & 19.95 \\
Cotopaxi & 7,000 & 350 & 5.00 \\
E. Regional Norte & 14,000 & 1.078 & 7.70 \\
Riobamba & 14,000 & 633 & 4.52 \\
Sierra Total & $\mathbf{1 4 4 , 0 0 0}$ & $\mathbf{2 1 , 0 8 4}$ & $\mathbf{1 4 . 6 4}$ \\
National Total & $\mathbf{3 3 0 , 0 0 0}$ & $\mathbf{4 9 , 5 2 3}$ & $\mathbf{1 5 . 0 1}$ \\
\hline & & &
\end{tabular}

\section{Conclusions}

Due the high power consumption of household refrigerators, many Latin American countries are implementing plans and programs of efficient refrigerators renewal, for the case of Ecuador the program called Renova Refrigerator was implemented.

The severe power crisis faced by Ecuador in the period from 1990 to 2009 was mainly due to economic problems and the lack of political decisions to implement projects that had already been studied by the defunct Ecuadorian Institute of Electrification (Instituto Ecuatoriano de Electrificación - INECEL). Today, a new structure has appeared with the Ministry of Electricity and Renewable Energy (Ministerio de Electricidad y Energía Renovable - MEER) as the governing entity for the development of policies, plans and programs that offer a better future for the electric sector of Ecuador, including energy efficiency programs.

The results savings accumulated and the number of replaced refrigerators, obtained in this study, set out from analysis of the savings achieved in a sample of customers of the Electric Company Southern Regional Center.

The renovation plan of domestic refrigerators was established to benefit a segment of the population classified by the power consumption, in this sense two tariffs were defined, the first refers to households that consume up to $110 \mathrm{kWh} /$ month for the Sierra region and $130 \mathrm{kWh} /$ month for the Coast region, called rate of dignity, second rate refers to consumption of $200 \mathrm{kWh}$ for the two regions. 
It has been shown savings of approximately $30 \mathrm{kWh} /$ month per customer classified in the category of monthly consumption between 110 and 200 $\mathrm{kWh}$ and a saving of $13 \mathrm{kWh} /$ month per customer classified in the category of lower consumption to 110 $\mathrm{kWh}$ (rate dignity).

It has been verified that the expected savings for the two rates, do not comply with estimated by the MEER on the basis of this program document. For the analysis two scenarios were established, one "real" and an "optimistic" or expected. With this analysis approach, goals for calculating the expected savings can have a significant deviation, may be less than $48 \%$ of the initially estimated. To perform the calculation newly subscribers who incorporated the efficient equipment at home were considered, to ensure that there should be no greater or profound changes in the energy use behavior.

The renovation plan of domestic refrigerators sets a goal of renewal of 330,000 units in 5 years, to meet this goal distribution equipment was planned for rates of electricity consumption in the order of $60 \%$ for the rate of dignity (consumption up to $110 \mathrm{~kW} /$ month for the Sierra region, $130 \mathrm{kWh} /$ month for the coast region) and $40 \%$ for lower consumption rate of 200 $\mathrm{kWh} /$ month region. A distribution plan according to the number of subscribers who have the power companies at the level of the Sierra region and coast region was performed.

The energy savings calculated from this study based on the Renova Refrigerator program show results approximately $50 \%$ lower than originally expected. The analysis defines two scenarios, one "real" and one "optimistic", for which the energy savings resulting from the Renova program were obtained.

The replacement process has been delayed in relation to the original annual strategy of the program; approximately $15 \%$ of the program has been implemented regarding to the 330,000 expected units despite having completed its third year of the five-year program.

Given the obtained values from the distributors, it is recommended to review the goals and/or units chosen by the program. Otherwise, the planned energy savings will not be achieved.

In spite of the programs established by MEER to reduce energy losses in Ecuador, there is a lack of dissemination of achievements and of awareness campaigns to generate cultural changes in energy usage.

Refrigeration is a field of study and application that is very extensive, and its increasing use presents opportunities that universities can take advantage of to produce specialists in this field. In the household sector, there are considerable empirical applications in the maintenance of refrigeration units, which can alter their original conditions and cause changes that affect their energy performance.
The imposed mandatory regulations and the international conventions on environmental stewardship have pushed white goods manufacturers to improve their production processes. It is necessary and advisable to maintain these implementations for other appliances, and there should be regular reviews of the efficiency levels in a continuous improvement process.

\section{References}

[1] N. G. Jara Cobos and C. A. Isaza-Roldán, "Programas de eficiencia energética y etiquetado en el Ecuador - revisión del estado actual," in II Encuentro de tecnología e Ingeniería \& $X$ Simposio Internacional en Energías, Medellín, Colombia, 2014, pp. 1-12. [Online]. Available: https://goo.gl/D2rG1E

[2] M. R. Peláez Samaniego and J. L. Espinoza Abad, Eficiencia energética y ahorro de energía en el Ecuador. Energías Renovables en el Ecuador - Situación actual tendencias y perspectivas, 2015, vol. 1, pp. 212-255. [Online]. Available: https://goo.gl/3VL1kV

[3] Ministerio de Electricidad y Energía Renovable, "Dirección nacional de eficiencia energética," 2016. [Online]. Available: https://goo.gl/7VMmQZ

[4] D. M. Álvarez and N. G. Jara, "Evaluación de los impactos en el consumo de energía eléctrica asociados al uso de refrigeradores eficientes en el Ecuador: Programa Renova Refrigerador," in Universidad Politécnica Salesiana, Cuenca - Ecuador, 2013.

[5] G. Zabala Aznar and G. Quiroga Prado, "Industria de electrodomésticos 2013," in ProMéxico Inversión y Comercio, 2013.

[6] L. C. Cando Cevallos, "Análisis de la incidencia del cambio de la matriz de producción en la capacidad de producción de cocinas de inducción en el sector de la línea blanca del Ecuador en el período 2007-2013," in Universidad Católica de Santiago de Guayaquil, Ecuador, 2016.

[7] B. Cornejo Castro, M. Naranjo, B. F. Pareja, and M. Montúfar, Ecuador, CEPAL - Naciones Unidas, 2002.

[8] U. Kuffner, "El proceso de la formulación de la política y estrategia de manejo de los recursos hídricos en el Ecuador," Santiago Chile CEPAL, vol. 2, pp. 23-34, 2005.

[9] CONELEC, Perspectiva y expansión del sistema eléctrico ecuatoriano - Volumen III - Plan maestro de electrificación 2013-2022, Ministerio de Electricidad y Energía Renovable, 2013. 
[10] — Estudio y gestión de la demanda eléctrica - Volumen II - Plan maestro de electrificación 2013-2022, Ministerio de Electricidad y Energía Renovable, 2013.

[11] P. Carvajal and A. Orbe, Balance Energético $\mathrm{Na}$ cional 2013, Ministerio Coordinador de Sectores Estratégicos, 2013.

[12] ARCONEL, Balance Nacional de Energía Eléctrica, 2015. [Online]. Available: https://goo.gl/vogMdv

[13] —, Boletines Estadísticos, 2014. [Online]. Available: https://goo.gl/bVEQuD

[14] G. Salazar and B. Panchi, "Análisis de la evolución de la demanda eléctrica en el Ecuador considerando el ingreso de proyectos de eficiencia energética," Rev. Politécnica, vol. 33, no. 1, 2014. [Online]. Available: https://goo.gl/mfqWKU

[15] A. B. Escandón, "Desarrollo de la tecnología de generación eólica en el Ecuador." Universidad de Cuenca, Ecuador, 2012.

[16] J. A. O. Espinoza and N. G. J. Cobos, "Modelo de dinámica de sistemas para determinar la influencia de la implementación de planes de renovación de refrigeradores domésticos en los procesos de oferta y demanda-caso Ecuador." Universidad Politécnica Salesiana, Ecuador, 2016.

[17] INEC, Encuesta Nacional de Ingresos y Gastos de los hogares urbanos y rurales 2011-2012, Ecuador, 2012 .

[18] B. C. Castro, M. Naranjo, B. F. Pareja, and M. Montúfar, "Anexo técnico renovadora para la implementación operativa y económico-financiera del "programa para la renovación de equipos de consumo energético ineficiente. Proyecto no. 1: Sustitución de 330000 refrigeradoras," in CEPAL - Naciones Unidas, 2014.

[19] N. G. Jara, C. Isaza-Roldán, L. Gallón, and D. P. Giraldo, "Modelo dinámico para el estudio de la aplicación del plan de renovación de refrigeradores domésticos en Colombia," in XIII Congreso Latinoamericano y Encuentro Colombiano de Dinámica de Sistemas, Cartagena, Colombia, 2015 .

[20] Secretaría de Gestión de Riesgos, Plan Estratégico Institucional 2014-2017, 2014.

[21] A. Chávez Peñaherrera, Estadística del sector eléctrico ecuatoriano 2014, Agencia de Regulación y Control de Electricidad, 2014. 